Diabetologia 10, 655-659 (1974)

(C) by Springer-Verlag 1974

\title{
Lipolysis and Adenosine 3'5'-Cyclic Monophosphate in Adipose Tissue of the New Zealand Obese Mouse; The Activities of Adipose Tissue Adenyl Cyclase and Phosphodiesterase
}

\author{
C.J. Lovell-Smith and J.G.T. Sneyd \\ Department of Clinical Biochemistry, University of Otago Medical School, Dunedin, New Zealand
}

\begin{abstract}
Summary. Cyclic $3^{\prime}, 5^{\prime}$ nucleotide phosphodiesterase and adenyl cyclase were measured in homogenates prepared from isolated fat cells from obese (NZO/Bl) and normal mice. Young obese mice showed increased phosphodiesterase activity compared with controls. Older mice of both strains showed markedly diminished phosphodiesterase activity which, however, remained higher in tissue from the obese mice. - Adenyl cyclase activity was higher in tissue from both young and old obese mice than in tissue from controls of the same age. However, the
\end{abstract}

adenyl cyclase activity observed in homogenates of tissue from control animals was insufficient to account for the rate of rise of cyclic AMP in the intact tissue. - It is proposed that the increased phosphodiesterase activity in young obese mice accounts for the decreased cyclic AMP levels observed earlier in isolated fat cells.

Key words: NZO/Bl mice, obesity, adipose tissue, adenyl cyclase, phosphodiesterase.
In an earlier paper [15] we described the rates of lipolysis and levels of cyclic AMP in adipose tissue from New Zealand obese (NZO/Bl) mice. Our findings suggested that the diminution in lipolysis seen in fat cells from young obese mice was caused by a failure of the levels of cyclic AMP to rise in response to catecholamines. In the present work we describe measurements of the activity of the enzymes involved in the control of cyclic AMP metabolism. An increase in the activity of phosphodiesterase in adipose tissue from young obese mice may be the reason for the diminished levels of cyclic AMP noted earlier.

\section{Methods and Materials}

\section{Animals}

Male $\mathrm{NZO} / \mathrm{Bl}$ and $\mathrm{NZY} / \mathrm{Bl}$ mice were obtained from the Hugh Adam Department of Cancer Research, University of Otago. They were fed and cared for as described previously [3]. NZY/Bl mice, of a non-obese inbred strain, were used as controls in all experiments. Isolated fat cells were prepared from the epididymal fat pads and incubated as described previously [15].

\section{Measurement of Phosphodiesterase Activity in Homo- genates of Fat Cells}

Phosphodiesterase activity in fat cell homogenates was assayed by the method of Loten and Sneyd [14]. Values for $\mathrm{Km}$ and Vmax were calculated by the method of Spears, Sneyd, and Loten [19].

\section{Measurement of Adenyl Cyclase Activity}

Many methods for the assay of adenyl cyclase in fat cells use radioactive ATP as the substrate, the labelled cyclic AMP formed during incubation being separated from other radioactive products $[17,1,21]$. The high cost of suitably-labelled ATP of high specific activity forced us to develop a method employing unlabelled ATP as the substrate. The cyclic AMP formed during incubation of cell homogenates with ATP was separated and assayed by the competitive protein-binding method of Gilman [6].

Isolated fat cells were washed twice in Krebs Ringer bicarbonate buffer [9], and once in $25 \mathrm{mM}$ glycylglycine buffer ( $\mathrm{pH} 7.5$ ) containing $2.0 \mathrm{mM} \mathrm{MgSO}$. The cells were then resuspended in $1.2 \mathrm{ml}$ of the same buffer, containing lecithin $(2.5 \mu \mathrm{g} / \mathrm{ml})$, lysolecithin $(2.5 \mu \mathrm{g} / \mathrm{ml})$ and $5.0 \mathrm{mM}$ ethyleneglycol-bis-( $\beta$-aminoethyl ether $) \mathrm{N}$ $\mathrm{N}^{\prime}$-tetracetic acid (EGTA). The addition of lecithin and lysolecithin to the homogenising medium increased the adenyl cyclase activity of homogenates by about $50 \%$; other combinations of phospholipids were less effective. The cells were homogenised by brief shaking in a glass test tube on a Vortex mixer.

The homogenate $(100 \mu \mathrm{l}$ containing the equivalent of $5-20 \mathrm{mg}$ of fat cells) was added to $125 \mu \mathrm{l}$ of the assay mixture containing 9.0 umole of Tris- $\mathrm{HCl}$ buffer $(\mathrm{pH} 8.0), 0.45 \mu$ mole of ATP, $1.125 \mu$ mole of $\mathrm{MgCl}_{2}$, $2.25 \mu$ mole of theophylline, $0.112 \mu$ mole of GTP, $225 \mu \mathrm{g}$ of bovine serum albumin and an ATP-regenerating system comprising phosphoenolpyruvate $(2.25 \mu$ mole $)$ pyruvate kinase $(1.2 \mu \mathrm{g})$ and myokinase $(1.25 \mu \mathrm{g})$. The mixture was shaken at $37^{\circ}$ for $10 \mathrm{~min}$.

The reaction was stopped by adding $0.5 \mathrm{ml}$ of $50 \mathrm{mM} \mathrm{HCl}$ containing tracer amounts of $\left[{ }^{3} \mathrm{H}\right]$ cyclic $\operatorname{AMP}(10,000 \mathrm{cpm})$ and placing the tubes in an ice bath. The cyclic AMP was purified by a modification of the technique already described [15]. Briefly, this involved sequential anion and cation-exchange column chromatography, the final acid effluent being lyophilised and taken up in $0.4 \mathrm{ml}$ of $500 \mathrm{mM}$ acetate buffer $(\mathrm{pH} 4.0)$. Cyclic AMP in this solution was assayed by the competitive protein-binding method. The radioactivity of 
an aliquot of the cyclic AMP solution in acetate buffer was determined and the recovery of cyclic AMP calculated; this was generally better than $60 \%$.

Small amounts of cyclic AMP were detected in unincubated fat cell homogenates. Some cyclic AMP came from the homogenised cells and the remainder appeared to be a contaminant of the ATP and phosphoenolpyruvate used. The total cyclic AMP from these sources was negligible compared with the amount produced during incubation of the homogenate.

Radioactivity was measured in a Packard Tricarb Model 3375 scintillation spectrometer, using the scintillation fluids and techniques previously described [15].

\section{Chemicals}

Crystalline porcine insulin (Lot $\mathrm{PH}$ 5589) and crystalline glucagon (Lot 258-234-B-167-1) were gifts from Dr. J. MeGuire of Eli Lilly and Co., Indianapolis, Indiana, U.S.A. Isoprenaline hydrochloride and noradrenaline bitartrate monohydrate were given by Winthrop Laboratories, Auckland N.Z. Crotalus atrox snake venom, crude bacterial collagenase (Lot 70C0300), myokinase, pyruvate kinase, ATP, phosphoenolpyruvate and bovine serum albumin were all purchased from the Sigma Chemical Co., St. Louis, Mo., U.S.A. Radiochemicals were purchased from the Radiochemical Centre, Amersham, England. $\left[{ }^{3} \mathrm{H}\right]$ cyclic AMP was purified before use as described previously [15]. Other chemicals used were of analytical grade.

\section{Results}

In previous experiments [15], cyclic AMP levels were measured in four groups of mice. These were $\mathrm{NZO/Bl}$ mice aged either 16-21 weeks ("young") or 14-21 months ("old") and NZY/Bl mice of similar ages. Mice of the same four age groups were studied in the present work. Young $\mathrm{NZO} / \mathrm{Bl}$ mice were gaining weight rapidly and were usually somewhat heavier than control mice of the same age, whereas old NZO/Bl mice were losing weight, but were nonetheless usually heavier than young mice of either strain. Obese mice reach a maximum weight at about 12 months, at which time they are heavier than obese mice of the ages studied in this work.

\section{Phosphodiesterase Activity}

Preliminary experiments with homogenates of isolated fat cells from young obese mice suggested the presence of two phosphodiesterases with different affinities for cyclic AMP. When ' $v$ ' was plotted against ' $v$ ' [[S], [7], two straight lines were obtained (Fig. 1), whereas one straight line is normally obtained for a single enzyme showing Michaelis-Menten kinetics. These findings could be caused by the presence of two phosphodiesterases, or by a single phosphodiesterase displaying negative cooperativity $[2,13,20]$. To show unequivocally that two enzymes are present it is ne- cessary to separate them. This was not attempted in the present work. Instead it was assumed that two phosphodiesterases were present and their kinetic parameters were calculated by the method of Spears et al. [19].

Table 1 shows $\mathrm{Km}$ and Vmax values for the phosphodiesterases in fat-cell homogenates from young $\mathrm{NZO} / \mathrm{Bl}$ and young $\mathrm{NZY} / \mathrm{Bl}$ mice. The $\mathrm{Vmax}$ of the

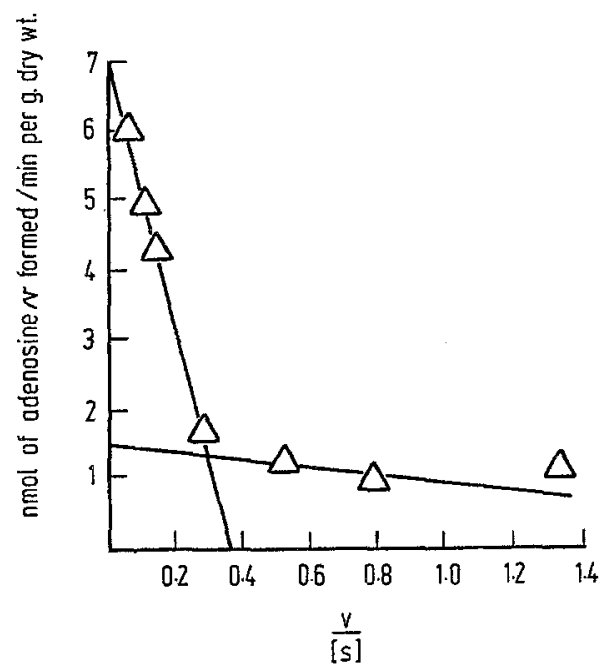

Fig. 1. Hofstee Plot (v against v/[S]) for phosphodiesterase activity in a homogenate of isolated fat cells from a young $\mathrm{NZY} / \mathrm{Bl}$ mouse

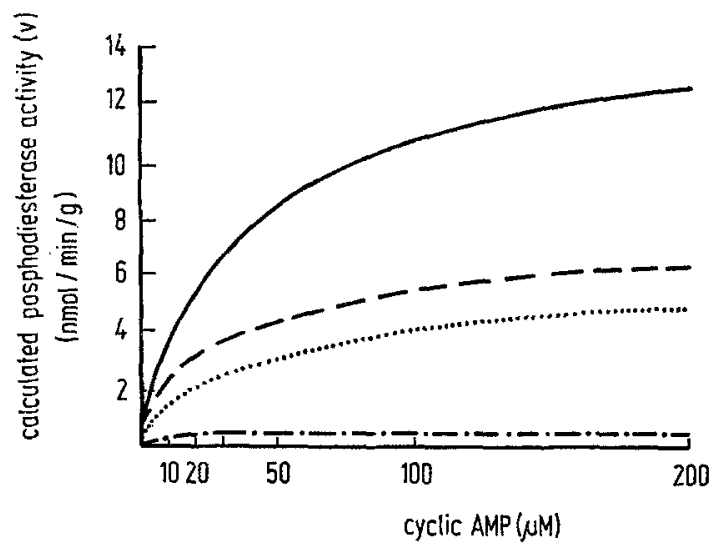

Fig. 2. Plot of $\mathrm{v}$ against [S] for adipose tissue phosphodiesterase. Values of $\mathrm{v}$ were calculated as described in the text, using the mean values for the kinetic parameters given in Table 1 and $2 . \ldots . . .$. Old NZY/Bl, ........ Old $\mathrm{NZO} / \mathrm{Bl}$, - - - Young NZY/Bl, — Young NZO/Bl

high $\mathrm{Km}$ enzyme from obese mice was much greater than that from controls, but other kinetic parameters were similar in the two strains. When old mice were studied (Table 2) the most striking finding was the absence of the high $\mathrm{Km}$ enzyme from fat cells from $\mathrm{NZY} / \mathrm{Bl}$ mice. In addition, the Vmax of the low $\mathrm{Km}$ enzyme was lower in homogenates of fat cells from old $\mathrm{NZY} / \mathrm{Bl}$ mice than in those from old $\mathrm{NZO} / \mathrm{Bl}$ mice. 
Using the values in Tables 1 and 2, the rate of hydrolysis of cyclic AMP by the two enzymes at various substrate concentrations may be calculated from the rearranged Michaelis Menten equation:

$$
\mathrm{v}=\frac{\mathrm{V}_{1}[\mathrm{~S}]}{\mathrm{K} \mathrm{m}_{1}+[\mathrm{S}]}+\frac{\mathrm{V}_{2}[\mathrm{~S}]}{\mathrm{Km}_{2}+[\mathrm{S}]}
$$

where $K m_{1}, V_{1}$ are the $K m$ and Vmax of one enzyme, and $\mathrm{Km}_{2}$ and $V_{2}$ the $\mathrm{Km}$ and $V \max$ of the other en. zyme, and [S] is the substrate concentration. Values of low levels of cyclic AMP earlier observed in these cells, we thought it necessary to assay adenyl cyclase in fat cells as well. A crude homogenate of isolated fat cells was used to avoid loss of activity during purification.

As shown in Table 3, the cells from obese mice had greater basal and fluoride-stimulated adenyl cyclase activity than did cells from controls. However, in neither strain did isoprenaline stimulate the activity of adenyl cyclase. The results of similar experiments on tissue from old mice are shown in Table 4. While the

Table 1. Kinetic parameters of phosphodiesterase activity of fat-cell homogenates from young obese and normal mice

\begin{tabular}{lcll}
\hline & $\begin{array}{l}\text { Young NZY/Bl } \\
\text { mice }\end{array}$ & $\begin{array}{l}\text { Young NZO/BI } \\
\text { mice }\end{array}$ & $\begin{array}{l}P^{\mathrm{a}} \\
(\mathrm{NZO} \text { v NZY })\end{array}$ \\
\hline $\begin{array}{l}\text { Low } \mathrm{Km}(\mu \mathrm{M}) \\
\text { Low Vmax }\end{array}$ & $1.20 \pm 0.44(11)^{\mathrm{b}}$ & $0.50 \pm 0.14(13)$ & $>0.10$ \\
(pmole/mg dry weight/min) & $1.58 \pm 0.43(11)$ & $1.20 \pm 0.22(13)$ & $>0.10$ \\
High Km ( $\mu \mathrm{M})$ & $55.1 \pm 12.5(11)$ & $52.0 \pm 5.44(13)$ & $>0.80$ \\
$\begin{array}{l}\text { High Vmax } \\
\text { (pmole/mg dry weight/min) }\end{array}$ & $5.89 \pm 1.24(11)$ & $14.4 \pm 1.48(13)$ & $<0.001$ \\
\hline
\end{tabular}

a $P$ values calculated by Student's $t$ Test

b Number of experiments in parentheses. Mean $\frac{1}{ \pm}$ S.E.M.

Table 2. Kinetic parameters of phosphodiesterase activity of fat-cell homogenates from old obese and normal mice

\begin{tabular}{llll}
\hline & $\begin{array}{l}\text { Old NZY } / \mathrm{Bl} \\
\text { mice }\end{array}$ & $\begin{array}{l}\text { Old NZO/Bl } \\
\text { mice }\end{array}$ & $\begin{array}{l}P^{\mathrm{a}} \\
(\mathrm{NZO} v \mathrm{NZY})\end{array}$ \\
\hline $\begin{array}{llll}\text { Low Km }(\mu \mathrm{M}) \\
\text { Low Vmax }\end{array}$ & $0.20 \pm 0.04(10)^{\mathrm{b}}$ & $0.87 \pm 0.22(10)$ & $<0.01$ \\
(pmole/mg dry weight/min) & $0.18 \pm 0.04(10)$ & $0.96 \pm 0.19(10)$ & $<0.001$ \\
High Km ( $\mu \mathrm{M})$ & - & $77.1 \pm 20.6(10)$ & \\
$\begin{array}{l}\text { High Vmax } \\
\text { (pmole/mg dry weight/min) }\end{array}$ & 0.00 & $5.44 \pm 0.77(10)$ & \\
\hline
\end{tabular}

a $P$ values calculated by Student's $t$ Test

b Number of experiments in parentheses. Mean \pm S.E.M.

Table 3. Adenyl cyclase activity in fat-cell homogenates from obese and normal mice

\begin{tabular}{llll}
\hline $\begin{array}{l}\text { Additions to the assay } \\
\text { system }\end{array}$ & \multicolumn{3}{l}{ Cyclic AMP formed (pmole/mg dry weight/10 min) } \\
\cline { 2 - 4 } & $\begin{array}{l}\text { Young NZY/Bl } \\
\text { mice }\end{array}$ & $\begin{array}{l}\text { Young NZO/Bl } \\
\text { mice }\end{array}$ & $\begin{array}{l}P^{\mathrm{a}} \\
\text { (NZO v NZY) }\end{array}$ \\
\hline Nil & $1.30 \pm 0.11(6)^{\mathrm{b}}$ & $2.52 \pm 0.47(5)$ & $<0.025$ \\
Isoprenaline $(0.89 \mu \mathrm{g} / \mathrm{ml})$ & $1.30 \pm 0.15(6)$ & $2.89 \pm 0.57(5)$ & $<0.02$ \\
NaF $(5.33$ mmole $/ \mathrm{l})$ & $4.02 \pm 0.40(6)$ & $9.21 \pm 2.24(5)$ & $<0.05$ \\
\hline
\end{tabular}

a $P$ values calculated by Student's t Test

b Number of experiments in parentheses. Means \pm S.E.M.

$\nabla$ derived in this way for the four groups of animals are plotted against [S] in Fig. 2. It can be seen that at any substrate concentration the rate of cyclic AMP hydrolysis would be greatest in fat cells from young NZO/Bl mice.

\section{Adenyl Cyclase Activity}

Although the high overall phosphodiesterase activity in fat cells from young obese mice might explain the activity of adenyl cyclase was apparently greater in homogenates of fat cells from obese animals the differences were barely significant.

\section{Discussion}

These findings show that the cyclic $3^{\prime}, 5^{\prime}$ nucleotide phosphodiesterase activity in adipose tissue from 
young $\mathrm{NZO} / \mathrm{Bl}$ mice is greater than in tissue from lean mice of the same age. In tissue from old lean mice, there was no detectable high- $\mathrm{Km}$ phosphodiesterase; and in tissue from old obese mice, the activity of the high $\mathrm{Km}$ enzyme was less than $40 \%$ of that seen in young mice. No reason can be advanced for this decrease in phosphodiesterase activity with age.

The cause of the elevated phosphodiesterase in fat cells from young obese mice is not immediately apparent. Because insulin can increase the rate of cyclic rate of formation of cyclic AMP in intact cells may be calculated from the rate at which cyclic AMP accumulates when the cells are incubated withisoprenaline and theophylline. This caleulation must underestimate the rate of formation of cyclic AMP because hydrolysis of cyclic AMP will be proceeding simultaneously, since theophylline does not completely inhibit the phosphodiesterase.

A comparison of the calculated minimum rate of cyclic AMP formation in intact fat cells and the fluor-

Table 4. Adenyl cyclase activity in fat-cell homogenates from obese and normal mice

\begin{tabular}{|c|c|c|c|}
\hline \multirow[b]{2}{*}{$\begin{array}{l}\text { Additions to the assay } \\
\text { system }\end{array}$} & \multicolumn{3}{|c|}{ Cyclic AMP formed (pmole $/ \mathrm{mg}$ dry weight $/ 10 \mathrm{~min}$ ) } \\
\hline & $\begin{array}{l}\text { Old } \mathrm{NZY} / \mathrm{Bl} \\
\text { mice }\end{array}$ & $\begin{array}{l}\text { Old } \mathrm{NZO} / \mathrm{Bl} \\
\text { mice }\end{array}$ & $\begin{array}{l}P^{a} \\
(\mathrm{NZO} \vee \mathrm{NZY})\end{array}$ \\
\hline & $0.84 \pm 0.19(5)^{b}$ & $2.28 \pm 0$ & $>0$ \\
\hline$g / \mathrm{m}$ & $0.98 \pm 0.27(5)$ & $2.60 \pm 0$ & $>0$ \\
\hline $\mathrm{Na}$ & $2.71 \pm 0.58(5)$ & $5.84 \pm 2$. & $>0$. \\
\hline
\end{tabular}

a $P$ values calculated by Student's t Test

b Number of experiments in parentheses. Means \pm S.E.M.

Table 5. Rate of accumulation of cyclic AMP by intact fat cells and homogenates of fat cells from obese and normal mice

\begin{tabular}{lll}
\hline & $\begin{array}{l}\text { Rate of cyclic AMP accumulation } \\
\text { (pmole/mg dry weight/min) }\end{array}$ \\
\cline { 2 - 3 } $\begin{array}{l}\text { Young NZY/B1 } \\
\text { mice }\end{array}$ & $\begin{array}{l}\text { Young NZO/B1 } \\
\text { mice }\end{array}$ \\
\hline $\begin{array}{l}\text { Intact cells } \\
\text { Homogenates of }\end{array}$ & $1.52 \pm 0.25(3)^{\mathrm{b}}$ & $0.12 \pm 0.02(3)$ \\
\hline
\end{tabular}

a Isolated fat cells were incubated for $5 \mathrm{~min}$ with isoprenaline $(1 \mu \mathrm{g} / \mathrm{ml})$ and theophylline $(1 \mathrm{mmole} / \mathrm{l})$. For the estimation of cyclic AMP levels the cells were homogenised in $4 \mathrm{mM}$ EDTA ( $\mathrm{pH} 4.5$ ) and the cyclic AMP extracted and estimated by the method of Gilman (1970). Cyclic AMP lovels were also measured before the addition of isoprenaline and theophylline. The rate of cyclic AMP formation in the intact tissue was taken as:

$$
\frac{\text { Cyclic AMP at } 5 \mathrm{~min}-\text { Cyclic AMP at zero time }}{5}
$$

Adenyl cyclase activity in homogenates of fat cells was measured in the presence of $5.33 \mathrm{mM} \mathrm{NaF}$ as described in the text.

$b$ Values are means \pm S.E.M. with the number of observations in parentheses.

AMP hydrolysis by rat adipose tissue phosphodiesterase, it is possible that the increased activity of the enzyme is a result of the chronic hyperinsulinism exhibited by the $\mathrm{NZO} / \mathrm{Bl}$ mice $[14,18]$.

The finding of increased adenyl cyclase activity in adipose tissue from young obese mice appears at first sight to exclude the possibility that diminished adenyl cyclase activity contributes to the low levels of cyclic AMP found here. However, it can be shown that the adenyl cyclase activity observed in homogenates of fat-cells is, in some cases, less than the rate of formation of cyclic AMP in intact fat cells. The minimum ide-stimulated adenyl cyclase activity of homogenates is made in Table 5. It is clear that, in the case of NZY/ $\mathrm{Bl}$ mice, the adenyl cyclase activity observed in homogenates was insufficient to account for the rate of accumulation of cyclic AMP levels in intact cells. However, the activity in homogenates of $\mathrm{NZO} / \mathrm{Bl}$ fat cells was greater than the calculated minimum activity in intact tissue. Thus the values obtained for adenyl cyclase activity in homogenates do not necessarily reflect the situation in whole tissue.

Adenyl cyclase in homogenates failed to respond to hormones that raised cyclic AMP in the intact tissue. Hormone sensitivity can be restored in solubilized systems by the addition of phospholipids to the assay system $[11,12]$. In this study, however, various combinations of phospholipids failed to restore the response to adrenaline of adipose tissue adenyl cyclase.

Previous reports on the activity of adenyl cyclase and phosphodiesterase in adipose tissue from obese animals are scanty. Adenyl cyclase and phosphodiesterase were assayed in homogenates of whole fat pads from $o b / o b$ and normal mice [5]. The activities of both enzymes, as expressed per $\mathrm{mg}$ of protein, were reduced in the preparations from the obese animals when compared with controls. Phosphodiesterase activity was also less than normal in adipose tissue of diabetic mice [10]. On the other hand, Mengel and Schwabe [16] stated that phosphodiesterase activity was $25 \%$ higher in adipose tissue from $o b / o b$ mice, and Kaplan et al. [8] found an increase in the $\mathrm{Km}$ as well as Vmax of the high $\mathrm{Km}$ enzyme in adipose tissue from mice of the same strain. It appears, however, that the reported changes would lead to an overall decrease in phosphodiesterase activity at low substrate concentrations.

Bray and York [4] suggested that, of all the known strains of obese rodents, $\mathrm{NZO} / \mathrm{Bl}$ mice were most likely 
to have a specific metabolic defect located in adipose tissue. The evidence presented in this paper has shown the presence of increased phosphodiesterase activity which could lead to the retention of lipid in triglyceride stores in young animals. The results obtained with older animals suggest that the changes are at least partially reversible with time. The role of adenyl cyclase activity in the control of cyclic AMP levels in obese mice is not clear because estimates of activity in homogenates did not always correspond to the calculated minimum rate of cyclic AMP formation in intact tissue. Much further work remains to be done before abnormalities in lipid synthesis or pancreatic function can be excluded as factors contributing to obesity in this strain of mice.

Acknowledgements. We thank Drs. M. Bielschowsky and C.M. Goodall for supplying the mice used in this study. C.J. Lovell-Smith is indebted to the Diabetic Association of New Zealand and to the Royal Australasian College of Physicians for Research Fellowships.

\section{References}

1. Bär, H.P., Hechter, O.: Adenyl cyclase in fat cell ghosts. Analyt. Biochem. 29, 476-489 (1969)

2. Beavo, J.A., Hardman, J.G., Sutherland, E.W.: Hydrolysis of cyclic guanosine and adenosine $3^{\prime} 5$ monophosphates by rat and bovine tissues. J. biol. Chem. 245, 5649-5655 (1970)

3. Bielschowsky, M., Bielschowsky, F.: The New Zealand strain of obese mice, their response to stilboestrol and to insulin. Aust. J. exp. Biol. med. Sci. 34, 181-198 (1956)

4. Bray, G.A., York, D.A.: Genetically transmitted obesity in rodents. Physiol. Rev. 51, 598-646 (1971)

5. Enser, M.: Fatty acid mobilization in obese mice. Nature (Lond.) 226, 175-177 (1970)

6. Gilman, A.G.: A protein binding assay for adenosine $3^{\prime} 5^{\prime}$-cyclic monophosphate. Proc. nat. Acad. Sci. (Wash.) 67, 305-312 (1970)

7. Hofstee, B.H.J.: On the evaluation of the constants $\mathrm{Vm}$ and $\mathrm{Km}$ in enzymatic reactions. Science 116, $329-331$ (1952)

8. Kaplan, J.-C., Pichard, A.-L., Laudat, M.-H., Laudat, P.: Kinetic and electrophoretic abnormality of cyclic AMP phosphodiesterase in genetically obese mouse adipocytes. Biochem. biophys. Res. Commun. 51, $1008-1014$ (1973)
9. Krebs, H.A., Henseleit, K. : Untersuchungen über die Harnstoffbildung im Tierkörper. Hoppe-Seylers Z physiol. Chem. 210, 33-66 (1932)

10. Kupiecki, F.P.: Reduced adenosine $3^{\prime} 5^{\prime}$ monophosphate phosphodiesterase activity in the pancreas and adipose tissue of spontaneously diabetic mice. Life Sci. (II) 8, 645-649 (1969)

11. Levey, G.S.: Restoration of norepinephrine responsiveness of solubilized myocardial adenylate cyclase by phosphatidylinositol. J. biol. Chem. 246, 7405$7410(1971 \mathrm{a})$

12. Levey, G.S.: Restoration of glucagon responsiveness of solubilized myocardial adenyl cyclase by phosphatidylserine. Biochem. biophys. Res. Commun. 43, 108-113 (1971 b)

13. Levitski, A., Koshland, D.E. : Negative cooperativity in regulatory enzymes. Proc. nat. Acad. Sci. (Wash.) 62, 1121-1128 (1969)

14. Loten, E.G., Sneyd, J.G.T.: An effect of insulin on adipose tissue adenosine $3^{\prime} 5^{\prime}$-cyclic monophosphate phosphodiesterase. Biochem. J. 120, 187-193 (1970)

15. Lovell-Smith, C.J., Sneyd, J.G.T.: Lipolysis and adenosine $3^{\prime} 5^{\prime}$-cyclic monophosphate in adipose tissue of the New Zealand obese mouse. J. Endocr. 56, 1-11 (1973)

16. Mengel, K., Schwabe, U.: Lipolyse an isolierten Fettzellen von fettsüchtigen Mäusen (obese mice). NaunynSchmiedeberg's Arch. Pharmak. 260, 126 (1968)

17. Rodbell, M.: Metabolism of isolated fat cells. V. Preparation of "ghosts" and their properties; adenyl cyclase and other enzymes. J. biol. Chem. 242, 5744$5750(1967)$

18. Sneyd, J.G.T.: Pancreatic and serum insulin in the New Zealand strain of obese mice. J. Endocr. 28, 163-172 (1964)

19. Spears, G., Sneyd, J.G.T., Loten, E. G.: A method for deriving kinetic constants for two enzymes acting on the same substrate. Biochem. J. 125, 1149-1151 (1971)

20. Teipel, J., Koshland, D.E.: The significance of intermediary plateau regions in enzyme saturation curves. Biochemistry 8, 4656-4663 (1969)

21. Vaughan, M., Murad, F.: Adenyl cyclase activity in particles from fat cells. Biochemistry 8, 3092-3099 (1969)

C.J. Lovell-Smith

Laboratory of Cellular Metabolism

National Heart and Lung Institute

National Institute of Health

Bethesda, Md. 20014,

USA 